\title{
O Contrato De Gláucon
}

\author{
Luiz Maurício Bentim da Rocha Menezes ${ }^{1}$
}

\begin{abstract}
Resumo: O Livro II da República de Platão se inicia com um desafio de Gláucon para Sócrates, onde este deve provar que o homem justo é, de toda maneira, melhor do que o injusto. Para isso, pedirá que Sócrates defenda a justiça por si mesma e censure a injustiça. O discurso de Gláucon pode ser dividido em três partes, sendo a primeira dedicada à origem e à natureza da justiça; a segunda irá indicar a justiça como algo necessário, mas não como um bem; e a terceira, na qual ele irá tentar provar que a vida do injusto é melhor do que a do justo. Neste trabalho, iremos nos centrar em seu primeiro argumento e de que maneira Gláucon defende a justiça através de um contrato.
\end{abstract}

Palavras-Chave: República de Platão. Desafio de Gláucon. Justiça. Contratualismo. Filosofia Política. Filosofia Antiga.

No Livro II da República de Platão, Gláucon pedirá que Sócrates defenda a justiça por si mesma e censure a injustiça, pois diz se sentir em

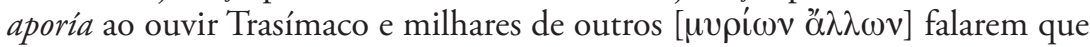
a vida do injusto é melhor do que a do justo, ao passo que falar a favor da justiça, como sendo superior a injustiça, ainda não ouviu ninguém falar, como é sua vontade. Por isso, irá reafirmar seu desafio a Sócrates de ouvir o elogio da justiça $\alpha u ̛ \tau o ̀ ~ \kappa \alpha \theta \theta^{\prime} \alpha u ̛ o^{2}$. No intuito de retomar Trasímaco, irá, dessa forma, dividir o seu discurso em três partes, as quais pretenderemos seguir em nosso trabalho:

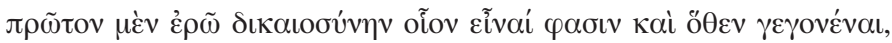

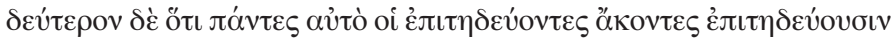

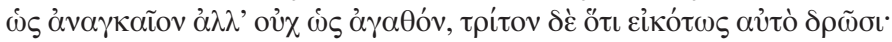

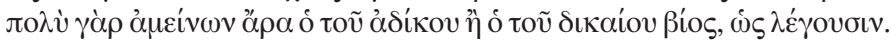

primeiro falarei o que dizem ser a justiça e sua origem, segundo que todos aqueles que a praticam, praticam por necessidade, mas não como um bem, terceiro que naturalmente procedem assim, porquanto, afinal de contas, a vida do injusto é muito melhor do que a do justo, no dizer deles. (Rep., 358c1-5).

\footnotetext{
${ }^{1}$ Professor de Filosofia Antiga e Filosofia Política da Universidade do Estado do Amapá (UEAP). Doutorando em Filosofia pelo PPGLM/UFRJ. E-mail: 1mbrmenezes@yahoo.com.br

http://dx.doi.org/10.1590/S0101-31732017000100012

2 PLATÃO, República, 358d. Utilizamos aqui a tradução de Maria Helena da Rocha Pereira $A$ República (Lisboa: Fundação Calouste Gulbenkian, 2001). Tomaremos essa tradução como base para nosso trabalho. Demais referências à 'República' serão abreviadas por Rep., indicando-se em seguida a numeraçáo. Para o original grego, utilizaremos o texto estabelecido por S. R. Slings, Platonis Rempublicam. Oxford: Oxford University Press, 2003. Todas as modificaçôes na tradução são nossas.
} 
No entanto, antes de iniciar sua exposição, Gláucon irá classificar o

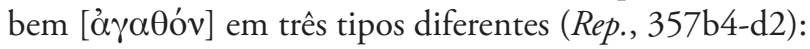

(i) O primeiro tipo de bem é aquele que desejamos, não por suas

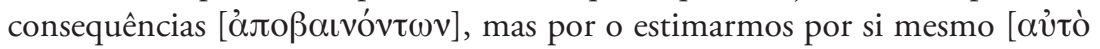
$\alpha$ i̛

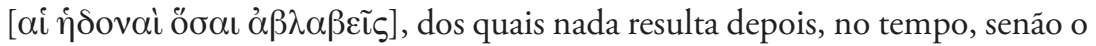

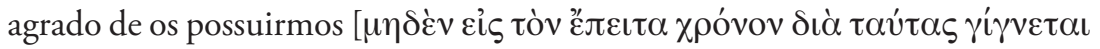

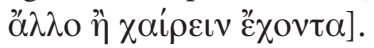

(ii) O segundo tipo de bem é aquele de que gostamos por ser agradável em si mesmo e pelas suas consequências, como a sensatez, a visão e a saúde [ö

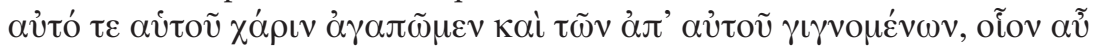

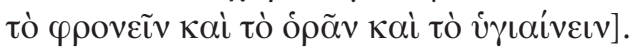

(iii) $\mathrm{O}$ terceiro tipo de bem é do tipo penoso, mas útil, e não aceitaríamos a sua posse por amor a ele, mas sim devido às recompensas e a

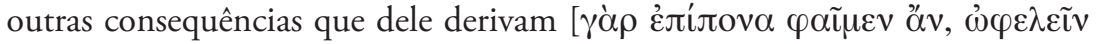

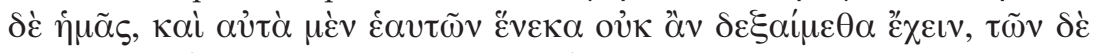

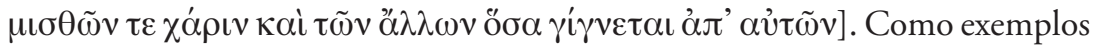
deste, temos a ginástica, o tratamento de doenças, a prática médica e outras maneiras de se obter dinheiro.

Sócrates irá colocar a justiça no segundo tipo de bem, enquanto Gláucon

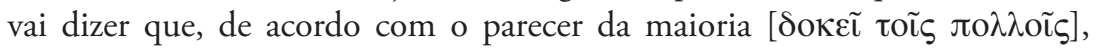
não é esse o tipo no qual a justiça se encaixa, porém, que pertence à espécie

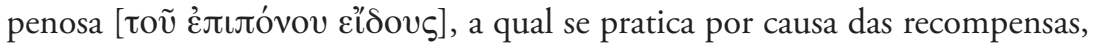
da reputação e das aparências, contudo, que por si mesma se deve evitar, como sendo dificultosa. Sendo o problema dos bens o da relação entre ser em si e a aparência (dóxa), Gláucon continuará seu argumento por uma defesa da relação da justiça apenas com a aparência.

Seu primeiro argumento (Rep., 358e2-359b5) tem o intuito de demonstrar a natureza da justiça, assim como sua origem, segundo o lógos

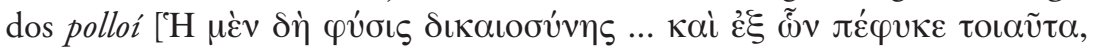

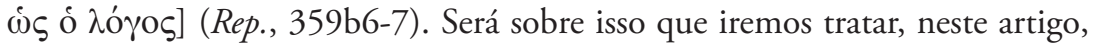
no intuito de fundamentar as bases que consagram o argumento de Gláucon como sendo do tipo contratualista. Nossa hipótese é que o contrato proposto por Gláucon contribuirá para a sua tentativa de defender o governo injusto, ao atrelar a este a dóxa da justiça, enfatizado quando ele diz que o suprassumo

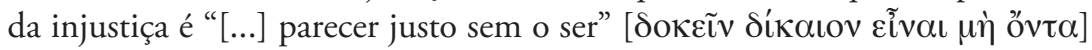


(Rep., 361a5). Nisso consiste o poder da tirania, governo este que, apesar de não ser citado por Gláucon, aparece implicitamente em seu argumento. Em nosso trabalho, utilizaremos fontes clássicas e contemporâneas, para fundamentar nossa hipótese.

\section{I}

Dizem os polloi que por natureza cometer injustiça é um bem, e sofrer

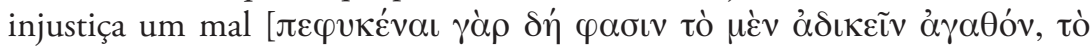

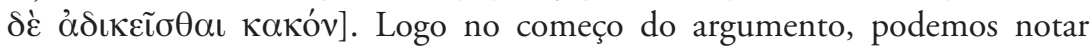
uma primeira dificuldade, que nos impede de prosseguir. A que tipo de bem estaria Gláucon aqui se referindo? Depois, ele usa o termo kakón (mal) por oposição a agathón (bem). Que tipo de relação esse novo termo estabelece com a classificação dos bens? Se tomarmos o ato de se cometer injustiça como um bem de primeiro tipo, teríamos que admitir que o próprio ato transmite prazer, ao ser feito. Todavia, se interpretarmos dessa maneira, tal ato injusto estaria ligado à perversidade, gerando prazer em se praticar injustiças apenas pelo ato em si, o que não parece ser o caso, já que a aquisição de algo posterior ao ato está em vista, ao se praticar injustiça. Ao analisarmos a classificaçáo dos bens, poderemos concluir que o bem de terceiro tipo é aquele que se pratica por causa da aparência (dóxa), se este assim a tiver, e em vista das recompensas el ou da reputação, mas que por si mesmo se deve evitar, como sendo dificultoso. Normalmente, assume-se que a injustiça possui uma aparência, e esta é ruim. ${ }^{3}$

No entanto, a aparência de injustiça só será julgada ruim depois da formação das leis e do nascimento da justiça, pois serão estas que darão as penas daquela. Na natureza, o homem que age pela injustiça não age pela dóxa, mas por considerar a injustiça útil para atingir os bens que tem em vista. É nesse sentido que Trasímaco parece colocar a injustiça como qualquer coisa

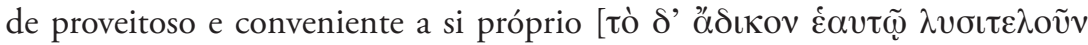

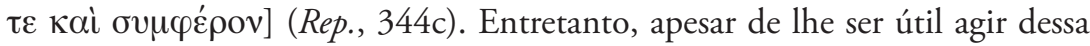
maneira, é também penoso, porque é trabalhoso conseguir seu objetivo. Pensando assim, colocaríamos o ato de cometer injustiça como, por natureza, um bem de terceiro tipo, sendo por si mesmo penoso para se praticar, mas útil, pois permite que se consigam as recompensas que tem em vista.

\footnotetext{
${ }^{3}$ Os exemplos de punição devido à dóxa da injustiça podem ser vistos nas passagens 361e-362a; e

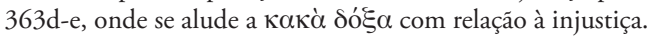


Quanto ao termo kakón, podemos justificar seu uso referente à pena sofrida pelo paciente da ação de se sofrer injustiça, que nada mais é do que algo prejudicial e não útil, por oposição a qualquer um dos bens. Dessa forma, o que se chama de mal aqui não é escolhido em hipótese alguma, não sendo desejado pelos homens.

Sofrer injustiça ultrapassa como um mal maior o bem que há em

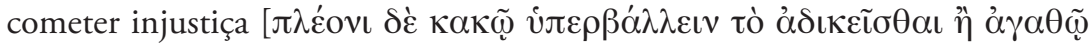

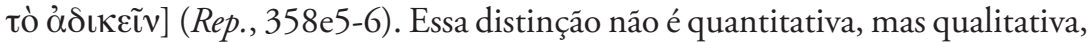
pois, para um homem, não há prazer suficiente em se cometer injustiça que seja melhor do que o desprazer que há em sofrer algum tipo de injustiça. Por isso, depois que os homens cometem e sofrem injustiças uns com os outros, e ambas são experimentadas, parece vantajoso aos menos capazes de evitar uma e alcançar outra estabelecerem um contrato mútuo, para não cometerem nem

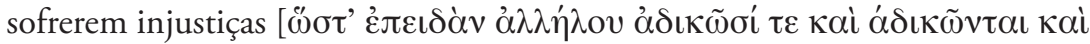

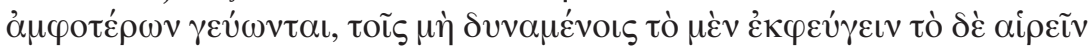

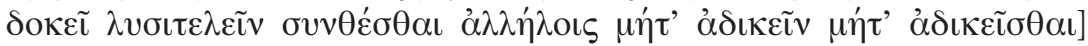
(Rep., 358e6-359a2). Aqui podemos notar que há um cálculo feito por esses homens que lhes permite medir o que vale mais a pena. Como os homens não conseguiam apenas o prazer de cometer injustiças e nem conseguiam evitar o desprazer de sofrer injustiças e, percebendo que este era muito pior do que o bem que aquele proporcionava, eles optaram pelo contrato, para se evitar sofrerem injustiça, mesmo que também não pudessem, com isso, continuar a cometer injustiça.

A partir do contrato se formariam leis, assim como a designação do

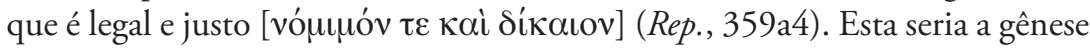
e a essência da justiça, sendo intermediária entre o melhor ser, não pagar a pena das injustiças cometidas, e o pior, ser incapaz de se vingar de uma

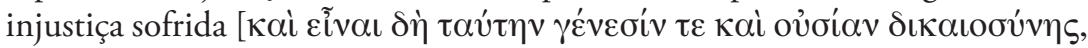

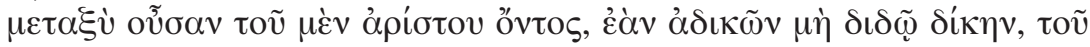

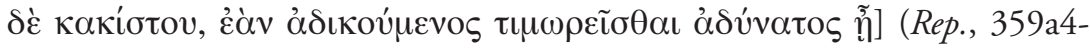
7). Nessa parte, podemos verificar que Gláucon atinge o primeiro propósito de seu argumento, que é demonstrar qual é a gênese da justiça. Por uma espécie de medida, os homens conseguiram pesar o que valia mais a pena e acabaram optando por um intermediário, o qual os poupasse das agruras da injustiça. Será a partir dessa formação que poderemos supor a distinção entre justo e injusto e de suas respectivas aparências. Com a determinaçáo das leis e o surgimento da justiça, a injustiça torna-se, além de penosa, também prejudicial, já que cometer injustiça implica agora uma punição da lei. 
Estando a justiça no meio de ambos, não é desejada como um bem,

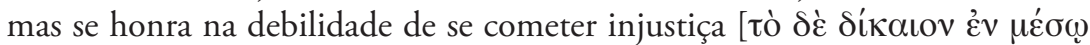

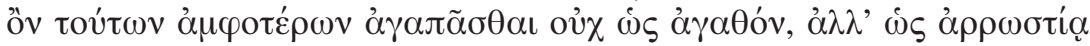

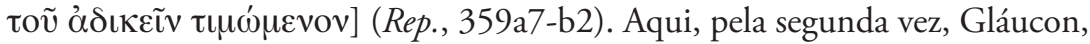

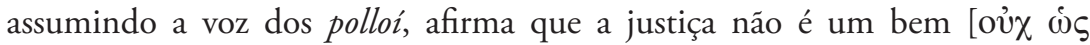
áy $\alpha \theta$ óv $]^{4}$. A passagem parece contrastar com a passagem 358a4-6, onde os polloi incluem a justiça no terceiro tipo de bem. Tal diferença faria com que ou a justiça, na visão dos polloí, não fizesse parte de nenhum tipo de bem, ou o terceiro tipo não fosse considerado por eles um bem. Qualquer uma das suposiçóes poria em risco a tripartição dos bens.

Para resolver o problema, temos de analisar o uso dos termos junto ao contexto. Primeiramente, não nos parece que Gláucon está colocando a justiça como sendo um mal do mesmo modo que sofrer injustiça o é, mas que a justiça não é vista pelos polloí como um bem, apesar de ser em si mesma um tipo de bem, o que, por si só, já difere de um mal. Depois, se tomarmos o que nos fala a classificação dos bens unicamente para cada tipo em si mesmo, veremos que o primeiro tipo de bem se refere às coisas que, em si mesmas, nos são bem-

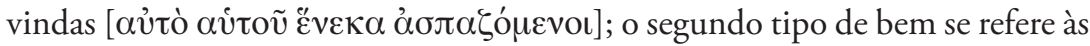

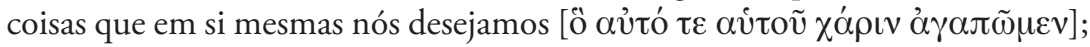
e o terceiro tipo de bem fala das coisas que em si mesmas não aceitamos ou

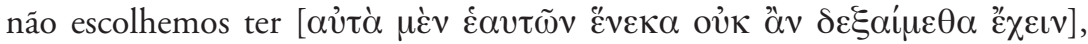

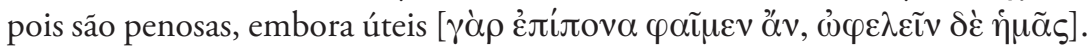
Entendendo o que é um bem em si mesmo, em cada um dos tipos, retomemos o que Gláucon fala da justiça, dentro de seu argumento. Ele diz que a justiça se encontra entre o melhor (áriston), que seria cometer injustiça sem ter que pagar por isso, e o pior (kákiston), que seria sofrer uma injustiça sem poder se vingar disso, dando a entender que a justiça tem utilidade, embora em

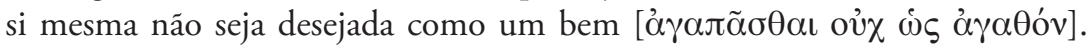
Queremos reforçar aqui o sentido de meio termo da justiça, porque, ao ser colocada numa posição central, permite medir e pesar as açôes dos homens, dando-lhes o que lhes é devido. Entendemos, desse modo, que o que Gláucon quer dizer em seu argumento é que a justiça não é um bem de primeiro tipo, pois em si mesma não é agradável, nem bem-vinda, e pelo mesmo motivo não pode ser colocada no segundo tipo, no entanto, mesmo não sendo escolhida por si mesma por ser penosa, a justiça tem sua utilidade, porque evita que injustiças sejam cometidas e sofridas, o que faz dela uma necessidade entre os

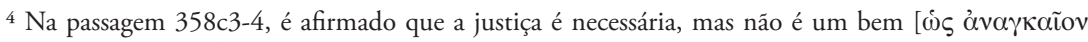
$\dot{\alpha} \lambda \lambda^{\prime}$ ở $\chi \hat{\omega} \zeta \hat{\alpha} \gamma \alpha \theta$ óv]. 
homens. Sendo, assim, a justiça se encontraria no terceiro tipo de bem.

Contudo, continuará Gláucon, em seu argumento, dizem que aquele que for capaz de fazer injustiças, e que seja um verdadeiro homem, não aceitaria o contrato de não cometer nem sofrer injustiças, pois seria loucura

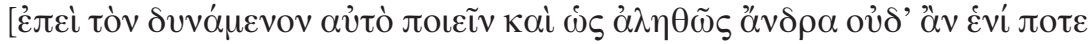

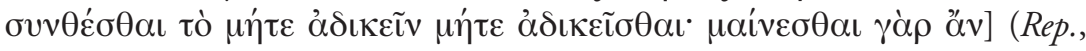
359b2-5).

Nessa exposição que fizemos, fica clara a oposição entre dynámenos e mè dynámenos. O dynámenos é aquele capaz de romper com o contrato, sem sofrer consequências negativas por isso. Mas a pergunta que nos fica é que homem, por mais forte que seja, é capaz de romper com o contrato? Para melhor esclarecer detalhes do argumento, levantaremos aqui algumas hipóteses.

Se supuséssemos que as pessoas vivessem numa pólis antes do contrato, teríamos que aceitar que a pólis não teria nenhum tipo de acordo ou contrato, sendo, dessa forma, a injustiça livre entre os homens, o que faz tudo ser permitido. A pólis é o que une os homens de maneira permanente, do contrário, não viveriam juntos nesta. Porém, dentro desta, todos cometem injustiças uns com os outros. Cometer injustiça é um bem, mas sofrer injustiça um mal, e tudo que lhes faz mal os homens querem afastar de si. Supondo que X, Y e Z são homens que vivem nessa pólis, tomemos que $\mathrm{X}$ comete injustiça com $\mathrm{Y}$; $\mathrm{Y}$ comete injustiça com $Z$; $Z$ comete injustiça com $X$; ora, teremos decorrente disso que $\mathrm{Y}$ se afasta de $\mathrm{X}$; Z se afasta de $\mathrm{Y}$; X se afasta de $\mathrm{Z}$. Isso pode ser repetido entre os demais elementos do conjunto, de maneira aleatória. Se sofrer injustiça é um mal maior do que o bem que há em cometer injustiça, os homens acabam ficando afastados uns dos outros. Assim, podemos concluir que não há nada na pólis capaz de unir os homens que seja mais forte do que o poder de afastamento que há em se sofrer injustiça. Logo, os homens irão se afastar uns dos outros e não viverão numa pólis, já que o motivo de esta existir é unir os homens de alguma forma. Mesmo que pudéssemos considerar a vingança, ao invés do afastamento, isso não seria suficiente para supor uma pólis antes do contrato. Portanto, as pessoas não vivem numa pólis antes do contrato. Seguindo essa linha de pensamento, os homens, anteriormente ao contrato, nada têm no mundo que os una de forma permanente. Ao se encontrarem, os homens cometem, assim como sofrem, injustiças uns com os outros, no entanto, sofrer injustiça é um mal maior do que o bem que há em cometer injustiça, não sendo esta capaz de criar concórdia entre os homens, como bem nos lembra Sócrates, em seu diálogo com Trasímaco, no Livro I: 


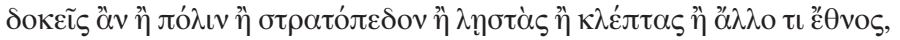

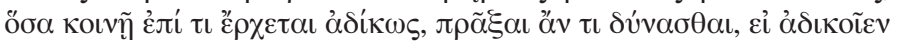

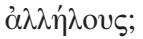

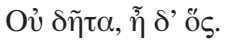

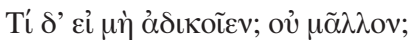

Пóvv $\gamma \varepsilon$.

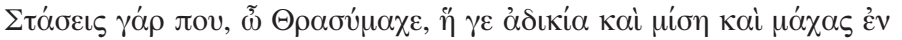

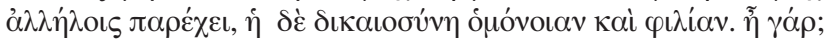

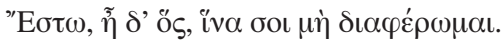

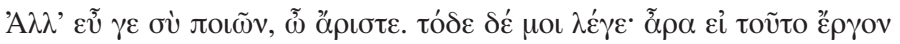

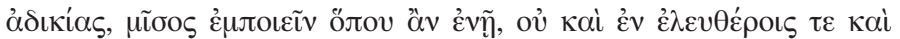

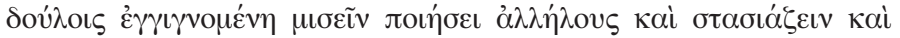

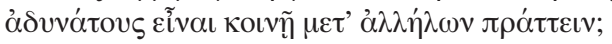

$\Pi \alpha \dot{v} v \gamma \varepsilon$.

- [...] parece-te que uma pólis ou um exército, piratas, ladrōes ou qualquer outra classe, poderiam executar o plano injusto que empreenderam em comum, se não observassem a justiça uns com os outros?

- Certamente que não - respondeu.

- E se a observassem? Não seria melhor?

- Absolutamente.

- Decerto, Trasimaco, é porque a injustiça produz nuns e noutros as revoltas, os ódios, as contendas; ao passo que a justiça gera a concórdia e a amizade. Não é assim?

- Seja - respondeu -, só para não discutir contigo.

- Fazes bem, meu excelente amigo. Mas diz-me o seguinte: se, portanto, é este o resultado da injustiça - causar o ódio onde quer que surja - quando ela se formar entre homens livres e escravos, não fará também com que se odeiem uns aos outros, com que se revoltem e fiquem incapazes de empreender qualquer coisa em comum?

- Precisamente. (Rep., 351c7-e3).

Trasímaco julga que a injustiça por sua própria força despótica pode tomar todos os bens que deseja e fazer seu possuidor feliz. No entanto, Sócrates demonstra que, se o érgon da injustiça é causar o ódio onde quer que surja, fazendo com que aqueles que a possuem fiquem incapazes de empreender 


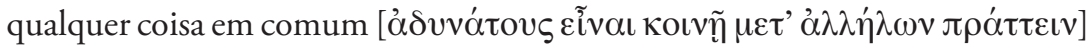
(Rep., 351d-e), entâo a injustiça não pode ser boa para aquele que a possui. Se considerarmos somente a injustiça entre os homens, estes viveriam em lutas e desavenças, sem nunca chegarem a um acordo. Tal efeito impossibilita qualquer tentativa de se estabelecer uma pólis. O que Gláucon pretende é retomar Trasímaco, seguindo outro caminho, já que o apresentado por este foi refutado por Sócrates. Irá, pois, supor uma natureza humana que busca cometer injustiça como um bem, por oposição à formação da lei e da justiça, que são a medida encontrada para evitar que o homem cometa injustiça, o que faz com que estas se originem junto ao contrato, nascendo, assim, a pólis. Logo, Gláucon narra a gênese da justiça como a gênese da pólis e menospreza sua ação sobre a alma.

Segundo Romilly (2002, p.1), a lei era entre os gregos o suporte e a garantia de toda sua vida política. Para explicar isso, ela irá traçar o caminho conceitual desenvolvido pelos gregos, para se chegar ao que eles entendiam por lei. Com a organização das cidades, no séc. VIII a.C., e o progressivo desaparecimento das monarquias, na Grécia, os direitos e as funçóes de cada um, em nome de um interesse comum, começam a se fixar e, assim, "[...] quando a lei surgiu, de uma forma ou de outra, os cidadãos tiveram acesso a vida política" (ROMILLY, 2002, p. 10-11). Todavia, será na Atenas democrática que a lei se destacará e se tornará célebre.

Com a aparição da democracia, a lei teve em Atenas o sentido que destacaria sua originalidade no pensamento grego. Melhor que qualquer princípio geral fixado em nome de uma revelação divina, melhor que as simples regras práticas que regulam a punição de certos crimes, as leis, no regime democrático, definiam, com o acordo de todos, os diversos aspectos da vida comum; e sua autoridade devia, assim, substituir a toda soberania de um indivíduo ou de um grupo, sentida como um insulto. (ROMILLY, 2002, p. 12-13).

Será na Atenas clássica, a qual surge das reformas de Clistenes, que a lei, fundamento e expressão da democracia, se torna lei política, se torna nómos (ROMILLY, 2002, p. 13). De acordo com Romilly, “[...] a palavra nómos, que designa a lei em grego, somente se aplicaria ao domínio político a partir desta época." (ROMILLY, p. 13). Para isso, ela se baseia na tradição, que utiliza a palavra para múltiplos sentidos, mas não a usa no sentido político (ROMILLY, 2002, p. 13-14). A palavra anterior empregada para denominar lei era thesmós, 
a qual é relativa à thémis, que designa a justiça, sob seu aspecto primitivo e divino (ROMILLY, 2002, p. 14, nota 6), e que foi progressivamente sendo substituída por nómos. Sólon mesmo parece se utilizar de thesmoí, para aludir às leis da cidade, e não parece empregar o nómos, no sentido de lei de uma cidade (ROMILLY, 2002, 14-15). Como a palavra thesmós desaparece na mesma época, Romilly se sente autorizado a pensar que o surgimento do nómos como lei política está ligado ao advento da democracia, e irá se apoiar na obra de Ostwald para afirmar que a palavra nómos, junto com a palavra isonomía, teria sido trazida para a vida política ateniense por Clistenes, em 506-507 (ROMILLY, 2002, p. 17). A lei, assim associada, será símbolo da oposição do ideal democrático contra a tirania, e também do ideal de uma vida política contra os bárbaros (ROMILLY, 2002, p. 18). Se entendermos o nómos, nesses termos, teremos que pensar, ao que parece, o surgimento da pólis narrada por Gláucon como o surgimento de uma pólis democrática, a qual teria leis comuns que garantiriam uma justiça igualitária para todos. No entanto, Gláucon parece entender o contrato de outra maneira, mais perspicaz em seu modo de pensar, que resultaria exatamente no contrário da defesa comum que se faz da lei como garantia da liberdade por oposição à tirania, conforme poderemos ver, no decorrer deste trabalho.

\section{II}

A teoria do contrato supóe uma noção de natureza humana, entendida como um princípio de insegurança em que os homens não estão livres de sofrerem os males da injustiça, e este princípio só é resolvido pela instauração de um governo que tem seu poder legitimado no contrato. A proposta de Gláucon dialoga com a sofística do séc. $V$ a.C., que investigava se a moralidade seria matéria da convenção (nómos) ou da natureza (phýsis), o que levanta questóes sobre o indivíduo e a pólis. Essa oposição entre a lei e a natureza foi reforçada pelos ensinamentos daquele século (ROMILLY, 2002, p. 97-111), no que se refere ao entendimento que se faz sobre a natureza humana e as convençóes da lei, o que aumentou a ocorrência da terminologia empregada pela sofística para caracterizar uma crise da lei (ROMILLY, 2002, p. 95). De acordo com Kerferd, a antítese nómos e phýsis "[...] sempre envolveu um reconhecimento da phýsis como uma fonte de valores e, portanto, em si mesma, de alguma maneira prescritiva." (KERFERD, 2003, p. 194). No período sofista, o apelo náo é para qualquer tipo de natureza, mas para a natureza do homem, em vista das demandas que brotam da própria natureza reforçando seu caráter prescritivo. 
Seguindo as teses de Charles Kahn, as teorias do contrato foram primeiramente formuladas por volta da segunda metade do século $\mathrm{V}$, como uma variante das primeiras declaraçóes sobre a origem da vida civilizada em sociedade, fontes estas que apresentam uma teoria geral de como o cosmos, as coisas vivas e os seres humanos originalmente vieram a existir (KAHN, 1981, p. 92). No entanto, os textos da primeira metade do século $V$ não tratam claramente sobre um contrato ou acordo. Nesse ponto, o sofista Antifonte parece ter sido o precursor da questão, argumentando que nómos e phýsis são opostos um ao outro, e que seguir o que é determinado pelo nómos entraria em conflito com a phýsis, prejudicando, com isso, o indivíduo (CURD, 2001, p. 150), como podemos ver em seu fragmento:

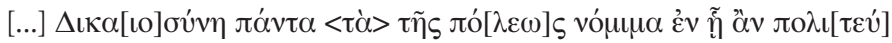

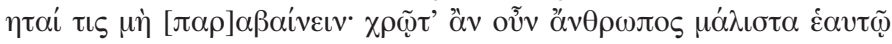

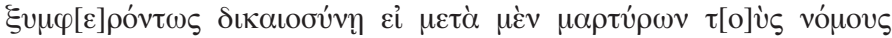

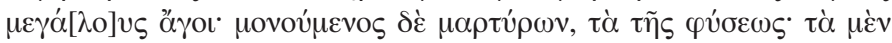

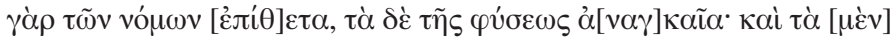

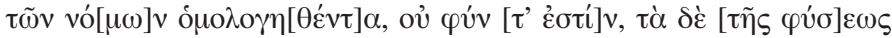

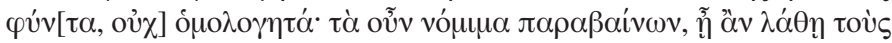

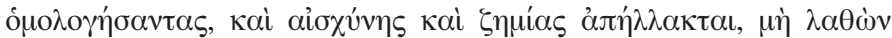

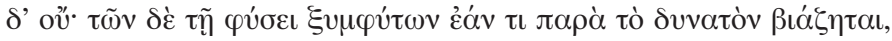

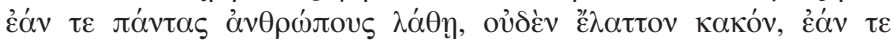

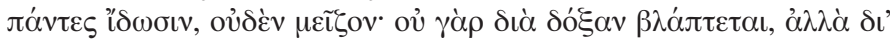

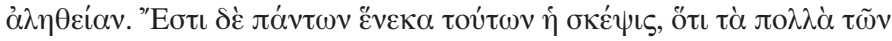

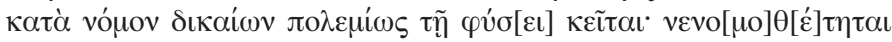

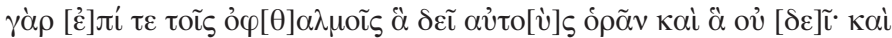

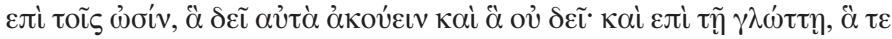

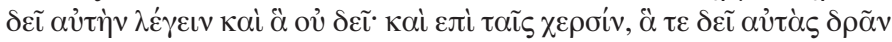

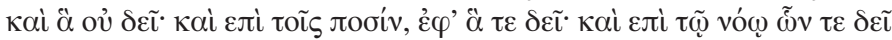

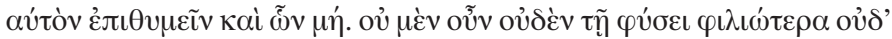

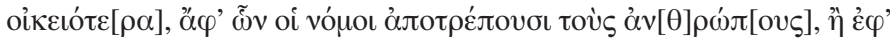

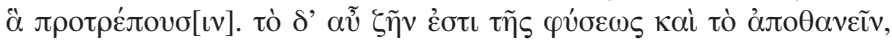

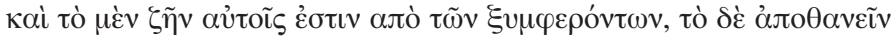

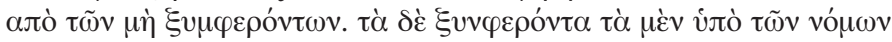

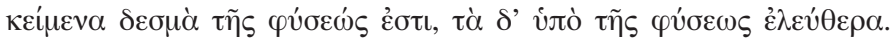

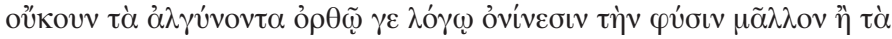

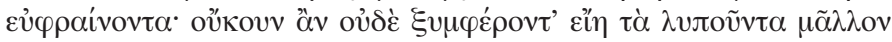

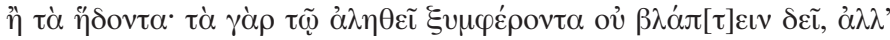
$\omega \varphi[\varepsilon] \lambda \varepsilon \tilde{v}$.

A justiça consiste em não violar as leis da pólis constituida de cidadãos. Um homem poderia empregar a justiça, sobretudo, para sua própria conveniência, se, diante de testemunhas, aplicasse as leis em profusão, mas, na ausência de 
testemunhas, seguisse as prescrições da natureza. Pois as prescriçóes das leis são instituidas, enquanto as da natureza são necessárias; o acordo das leis não é natural, ao passo que as prescriçóes da natureza são naturais, não acordadas. Assim, quando alguém transgredir as leis, a vergonha e a punição não o acometerão, se ele escapar aos olhos dos partícipes daquele acordo; mas não se não estiver oculto. Mas se, contrário ao possivel, alguém violasse alguma das coisas que são próprias por natureza, o mal não será menor se ninguém percebê-lo e nem maior se todos o observassem, pois não é prejudicado pela aparência, mas pela verdade. Este é todo o propósito de se considerar estas coisas que são justas por causa da lei de uma maneira e que são contrárias à natureza; pois são dispostas por lei aos olhos as coisas que devem ver e as que não devem; e aos ouvidos, as que devem ouvir e as que não devem; è lingua, as que ela deve dizer e as que não deve; e às mãos, as que devem fazer e as que não devem, e aos pés para onde devem ir e para onde não devem, e ao espírito, as coisas que deve desejar e as que não deve. Com efeito, não são para a natureza em nada mais afins nem mais próprias as coisas das quais as leis dissuadem os homens do que aquelas dos quais persuade. Por outro lado, o viver e o morrer são da natureza e, para eles, o viver é uma das coisas convenientes e o morrer uma das não-convenientes. As coisas convenientes fixadas pelas leis, por seu turno, são grilhöes da natureza, as fixadas pela natureza, livres. De fato, as coisas que produzem sofrimento, por uma correta razão, não são proveitosas à natureza mais do que as agradáveis; não seriam, portanto, em nada mais convenientes as coisas dolorosas do que as prazerosas. Pois as coisas convenientes, segundo a verdade, não devem prejudicar, mas serem úteis. ${ }^{5}$

Antifonte introduz a tese de que a justiça é um acordo [ó $\mu \mathrm{o} \partial \gamma \eta \theta \dot{v} v \tau \alpha$ ] que regula os nómoi da pólis. A conveniência [ $\xi v \mu \varphi \varepsilon \rho o ́ v \tau \omega \varsigma$ ] consiste em seguir a lei, quando se está sendo observado, mas se for possível ficar oculto aos demais e escapar do acordo, será conveniente que ele assim o faça, porque as prescriçôes da natureza são prazerosas e necessárias [ảv $\alpha \gamma \kappa \alpha \tilde{\imath} \alpha$ ], ao passo que seguir as leis é penoso para o indivíduo. A noção de acordo, utilizada por Antifonte através da palavra ó $\mu \mathrm{o} \lambda \mathrm{o} \gamma \dot{i} \alpha$, é relacionada sempre com as leis, pois o acordo só é possível pelo estabelecimento de leis entre os homens, sendo totalmente excluído da natureza humana. Para Antifonte, a justiça repousa sobre um aparato legal: ele se recusa a aceitar que a lei possui alguma raiz natural, pelo contrário, "[...] o procedimento legal viola a necessidade material em todos os sentidos" (HAVELOCK, 1957, p. 259).

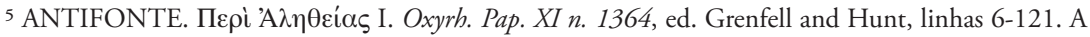
nossa tradução é baseada na tradução de Grenfell e Hunt. Também consultamos a tradução de Luís Felipe Bellintani Ribeiro, Antifonte. São Paulo: Loyola, 2008, p. 72-75.
} 
No entanto, não pensamos que Antifonte está defendendo uma transgressão da lei por princípio, mas que ele está demonstrando que o justo é garantido pela lei, e que esta preserva a vida em comum dentro da pólis, apesar de que o seu oposto, que é a própria natureza, é considerada vantajosa e deve ser seguida, se assim for possível, já que transmite prazer àquele que a pratica. $\mathrm{O}$ fato de ser visto ou não e da maneira como se é visto faz toda a diferença dentro do pensamento de Antifonte. A transgressão da lei não é um problema para o agente, mas somente se este for visto em seu ato, e essa acuidade de visão está ligada à verdade [ả $\eta \theta \varepsilon i \alpha v]$, pois, segundo Antifonte, pela

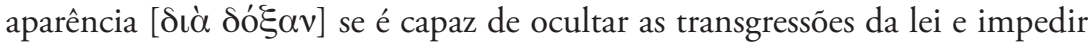
a observância da mesma. A verdade é colocada como sendo a única capaz de

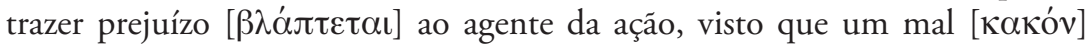
pode ser por ele ocultado da percepção dos demais, através da dóxa. Mas nem tudo que é phýsis é conveniente para Antifonte, pois a morte, por exemplo, é

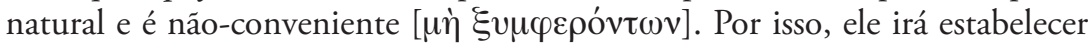
um outro critério, de acordo com o qual certo e errado se identificam com utilidade e prejuízo:

É o que é útil ${ }^{6}$ ao homem e a sua natureza que está sendo tratado como bem, e argumenta-se que as provisóes das leis e normas da sociedade não favorecem a natureza mas, ao contrário, são grilhôes e cadeias impostas a ela que impedem, em vez de favorecer, a sua realizaçáo. Isso deixa aberta a questão de saber se, excepcionalmente, algumas leis podem favorecer a natureza. (KERFERD, 2003, 198-199).

Saber, em Antifonte, se as leis, em alguns momentos, podem favorecer a natureza é uma questão ainda sem resposta, conforme Kerferd ressalta acima. Mas não podemos deixar de pensar que é essa a questão que gira em torno das relaçóes entre justo e injusto, da maneira como são colocadas por Gláucon, o qual traz esses importantes conceitos para o debate nómos-phýsis, já bastante conhecido na época de Platão. Muito do que é enfatizado por Antifonte é por Gláucon empregado, mas, em seu argumento, ele coloca o ato de se cometer injustiça como um bem que é naturalmente desejado pelo homem e a justiça é, por oposição, determinada pelas leis impostas pelo contrato. Antes de darmos seguimento à análise disso, em nosso trabalho, queremos atentar para o fato de que Antifonte ainda não usa a

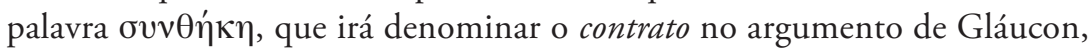

6 Trocamos aqui "benefício", utilizado por Kerferd, por "utilidade", para que o termo entre de acordo

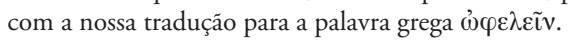


já que essa palavra, de acordo com Kahn, só será empregada pela primeira vez para caracterizar uma relação contratual entre cidadãos no Criton de Platão ${ }^{7}$, o que já pode ser um indício de que a noção de contrato já fosse suficientemente familiar, no início do século IV (KAHN, 1981, p. 94-95).

Entretanto, uma referência a uma primeira noção de natureza humana e estabelecimento de uma pólis atrelada ao contrato irá aparecer somente com o discurso proferido por Gláucon, no Livro II da República. Nele, podemos perceber que o homem, de maneira geral, é mè dynámenos e não pode, nesse momento pré-contratual, evitar sofrer injustiça de algum modo. Parece-nos mais provável, e coerente com o argumento de Gláucon, que todos os homens são suscetíveis a sofrerem injustiças. Antes do contrato, a fragilidade está nos próprios homens, incapazes de cometerem injustiça sem que sofram também com elas. Após a formação do contrato, o risco está num tipo específico: o dynámenos, pois é este, e somente este, que consegue recusar o contrato, por ter força suficiente para continuar a fazer injustiças,

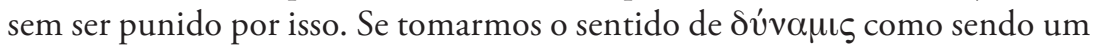
princípio de ação que tem como consequência imediata a produção de um érgon (AUGUSTO, 1996, p. 32-33), poderemos entender que dynámenos, de acordo com o contexto estabelecido por Gláucon, é todo aquele que consegue, mesmo que por uma só vez, cometer injustiça. Feito isso, temos ainda duas observaçôes a serem feitas.

Primeiramente, é dito por Gláucon que todos os homens experimentam tanto cometer como sofrer injustiças, o que nos parece mais do que suficiente para entender que nenhum homem pode ser sempre dynámenos, pois não há homem, por mais forte que seja, capaz de cometer injustiça, numa situação pré-contratual, que não seja também alvo da injustiça. Seguindo essa linha de pensamento, poderíamos considerar que os homens podem ser ora dynámenoi, ora mè dynámenoi, ou seja, conseguem algumas vezes cometer injustiça e outras não, sofrendo desta também. Desse modo, não existiria dynámenos de maneira duradoura, mas somente circunstancial.

Para esclarecer o segundo motivo, vamos supor que, entre os homens, um deles fosse maior em dýnamis do que os outros, e que este, com sua força, conseguisse cometer injustiça livremente, sem sofrer desta. Se os homens, ao criarem o contrato para evitar sofrerem injustiças, conseguissem também

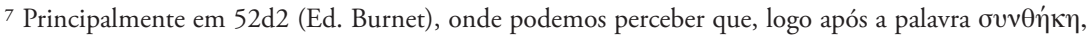
é inserida a palavra ó $\mu \mathrm{o} \lambda \mathrm{o} \gamma \mathbf{i} \alpha$, sendo uma semelhança com o fragmento citado de Antifonte, além de reforçar a ideia de convenção.
} 
evitar que esse homem atuasse injustamente, então ele não seria, estritamente falando, sempre dynámenos; caso contrário, se ele continuasse a cometer injustiça, sem ser punido pelo contrato que instituiu a justiça, o contrato seria inútil em seu fim, porque a injustiça continuaria a ser cometida por ele. Dessa maneira, ou o dynámenos se demonstra como insuficiente para náo aceitar o contrato, ou o contrato se demonstra insuficiente para evitar que injustiças sejam cometidas e sofridas. O verdadeiro dynámenos é aquele que pode burlar o contrato, não o aceitando de forma alguma, pois a ele este não pode afetar. Mas um homem assim, que fosse sempre dynámenos em suas açôes, não pode existir antes do contrato, porque a formação deste em nada evitaria a ação daquele.

Por isso, a hipótese da existência do dynámenos contínuo antes do contrato, aquele que nunca falha em suas ações injustas e também não é afetado pela injustiça, não nos parece consistente com a razão de o contrato existir, isto é, evitar injustiças. Poder-se-ia ainda levantar a hipótese de que o contrato só foi instituído para evitar a injustiça entre os mè dynámenoi, mas isso só levaria à conclusão de que o contrato já nasce fraco por princípio, e não parece este, a nosso ver, uma boa noção contratual. O contrato surge, porque é mais forte do que qualquer homem, uma vez que, através da instituição das leis e da justiça, é capaz de evitar que homens cometam e sofram injustiças uns com os outros. Por outro lado, é justamente depois de consumada tal

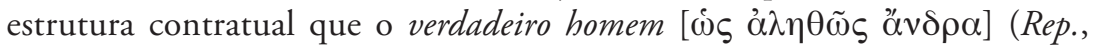
359b3) aparece como sendo alguém capaz de burlar tal estrutura, pois, para se consagrar como aquele que sempre consegue cometer a injustiça, sem ser alvo da mesma, precisa do contrato. Sendo assim, o contrato é uma força dúbia que tanto impede os homens de cometerem e sofrerem injustiça, como também permite ao verdadeiro dynámenos cometer injustiça, porque é o contrato, através da sua força, que possibilita a impunidade daquele. Poderemos, assim, distinguir terminologicamente o dynámenos, aquele que consegue por vezes cometer uma ação injusta, do verdadeiro dynámenos, que é aquele que sempre consegue cometer uma ação injusta, através do uso do contrato a seu favor. E esse caminho só será possível para aquele que, de alguma forma, consiga se assenhorear do governo e usar o contrato a seu favor. Será esse caminho que Gláucon parece expor, com seu argumento para se atingir a tirania.

A retomada do lógos de Trasímaco por Gláucon (Rep., 358b8-c1) não poderia deixar de passar pela tirania. Apesar de esta não ser mencionada 
textualmente por Gláucon, ela está implicitamente colocada no seu discurso. O verdadeiro governante [ $\dot{\omega} \varsigma \alpha \lambda \eta \theta \tilde{\omega} \varsigma \alpha \ddot{\rho} \rho \chi 0 v \sigma \iota v]$ (Rep., 343b5) seria aquele em que a pleonexía o leva a ser um grande dynámenos (Rep., 344a1), sendo

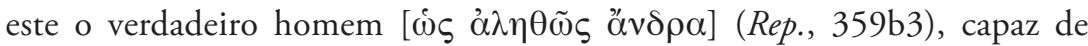
negar o contrato para si e, assim, arrebatar os bens dos governados e fazê-los escravos de seu governo. A colocação de Gláucon do contrato para marcar o surgimento das leis e da justiça, com o intuito de impedir que se possa cometer injustiça, permite que, da mesma maneira que o pastor e a ovelha de Trasímaco, o governante, que deveria preservar o contrato para proteger seus governados, na verdade se utilize deste para tirar proveito próprio, fazendo com que as leis, determinadas pelo contrato, o beneficiem acima dos demais. A diferença consiste em que Gláucon, ao supor uma dóxa que possibilita ao governante agir injustamente, demonstra como o injusto poderia agir pela injustiça, ao se passar por justo, ao contrário de Trasímaco, o qual não é capaz de dar essa resposta a Sócrates (Rep., 351c7-e3). Ao que parece, o tipo de governo que caberia dentro do quadro pintado pelo lógos dos polloí seria a tirania, que seria a mais completa injustiça (Rep., 344a4) e que é por eles tida como aquela que conduz à melhor forma de vida, devido aos bens que proporciona ao indivíduo e, por isso, consideram o tirano feliz e bem-

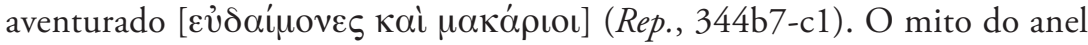
de Gyges (Rep., 359d-360b) parece apontar para o grande desafio existente dentro do campo ético-político. Irwin nos chama atenção para o problema que Gláucon coloca, logo no começo do Livro II, onde ele diz querer ver

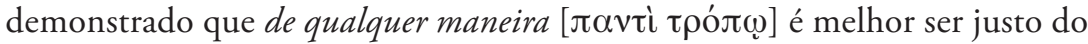
que injusto (IRWIN, 1999, p. 174-175). ${ }^{8}$ Se tomarmos isto como parte do desafio de Gláucon imposto a Sócrates, teremos que admitir que até mesmo em situaçóes contrafactuais, nas quais a injustiça parece ser extremamente vantajosa, como o exemplo de Gyges, a justiça deve ser escolhida por ser superior à injustiça.

Pois este desafio é, no limite, um desafio ao filósofo, convidado a refazer, de um certo modo, o percurso de Gyges. Porque a questão da tirania e a questão da justiça não se colocam apenas no âmbito das relaçóes entre os homens na sua melhor ordenação, mas também no âmbito das relaçóes da alma consigo mesma e na harmonia desejável entre suas partes. Política e filosofia se entrelaçam, reproduzindo na tensão entre o saber e a cidade, a tensão entre o inteligível e o sensível. (SCHALCHER, 1988, p. 108).

${ }^{8}$ A passagem da República é a 357b1. 
O desafio imposto pelo anel de Gyges parece-nos ainda muito pouco observado pelos estudiosos da República, e aqueles que dele falam, sequer examinam a tirania implicitamente colocada por seu autor à passagem estudada.

O Etymologicum Gudianum, 537.26 (STURTZ, 1818), assim define o

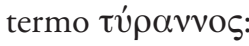

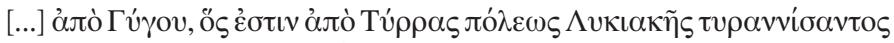

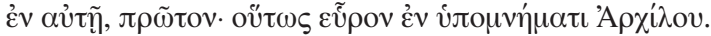

[...] de Gyges, que é de Týrras, cidade da Lícia, a qual, primeiro governou com tirania. Assim se falava na memória de Arquiloco.

E também no Etymologicum Magnum, 771.54 (SYLBURG, 1816):

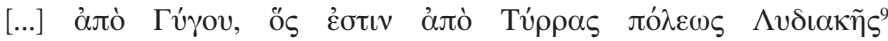

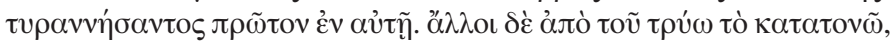

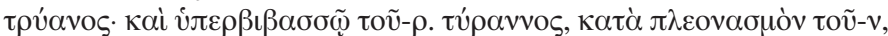

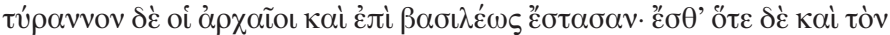

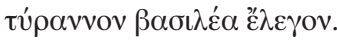

[...] de Gyges, que é de Týrras, cidade da Lidia, a qual, primeiro governou com

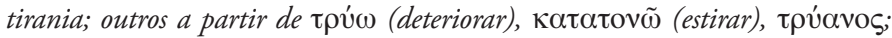
e pela transposição do $-\rho$ e pelo pleonasmo do $-v$, temos túpavvos (tirano). Os antigos também chamavam de tirano o rei, assim como rainha também era chamada tirano. ${ }^{10}$

A tradição lírica ${ }^{11}$ tem em conta a figura de Gyges como sendo um tirano, rico em ouro, senhor de homens que se iguala a um deus, em seus atos e desejo de poder. Ser completamente injusto é ser tirano e, para que isso possa se realizar, o injusto deve agir no limite de sua dýnamis, sabendo separar o que ele pode do que não pode fazer. A dýnamis do anel que o torna invisível é o que permite a Gyges agir como um tirano, pois o torna capaz de ocultar seus atos injustos dos demais. Se um homem pudesse separar adequadamente o que pode do que não pode fazer e soubesse o que deve ocultar, em suas açóes,

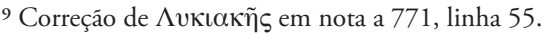

${ }^{10}$ Ambas as traduções do texto grego citado são nossas.

11 Para essa tradição, ver: ARQUÍlOCO, Fr. 19W; ALCMAN, Greek Anthology, VII.709.1-6; MIMNERMO, Fr. 13W; HIPPONAX, Fr. 42W; ANACREONTE, Fr. 8W; SEMÔNIDES, Fr. 7W. Para o argumento completo sobre tal tradição, ver: MENEZES, 2012, 2013, 2014.
} 
dentro das habilidades que competem ao verdadeiro injusto, entâo tal homem poderia atingir a tirania como a forma de governo que compete a tal homem e teria uma vida feliz. O fato de poder estar visível e invisível, quando quiser, faz da tirania o governo do injusto, o qual comete suas injustiças ocultamente, para obter aquilo que seu desejo indica como um bem; e parece justo quando visível está, enganando todos os demais que por ele são governados de que seu governo é bom e justo. Tal fato faz de Gyges o tirano por excelência, o que em muito contribui para o desenvolvimento do mito da tirania formulado por Platão.

MENEZES, Luiz Maurício Bentim da Rocha. Glaucon’s contract. Tans/form/ação, Marília, v. 40, n. 1, p. 235-252, Jan./Mar., 2017.

ABstract: Book II of Plato's Republic opens with Glaucon's challenge to Socrates, where the latter must prove that the just man is in all ways possible better than the unjust one. Glaucon asks Socrates to advocate justice for it's own sake and to censor injustice. Glaucon's discourse can be divided into three parts. The first is dedicated to the origin and nature of justice; the second argues that justice is something necessary, but is not a good. In the third part, he tries to prove that the unjust life is better than the just one. This work focuses on the first speech and on how Glaucon defends justice by means of a contract.

Keywords Plato's Republic. Glaucon's challenge. Justice. Contractualism. Political philosophy. Ancient philosophy.

\section{REFERÊNCIAS}

ADAM, J. The republic of Plato. Edição de J. Adam. Cambridge: Cambridge University Press, 1979. 2v.

ANNAS, J. An introduction to Plato's republic. Oxford: Oxford University Press, 1981.

AUGUSTO, M. G. M. O visível e o invisível nos argumentos do livro 2 da república. Textos de Cultura Clássica, n. 19, p. 19-42, 1996.

BLOOM, A. The republic of Plato. Tradução de Allan Bloom. New York: Basic Books, 1991 (1. ed. 1968).

CURD, P. Why Democritus was not a skepic. In: PREUS, A. (Org.). Before Plato. Albany: State University of New York Press, 2001. p. 149-169.

GRENFELL, B. P.; HUNT, A. S. The Oxyrhynchus Papyri. V. XI. Edited with translated and notes by B. P. Grenfell and B. P. Hunt. London: Oxford University Press, 1915. 
HAVELOCK, E. A. The liberal temper in greek politics. London: The Camelot, 1957.

IRWIN, T. H. Republic 2: questions about justice. In: FINE, G. Plato2. New York; Oxford: Oxford University Press, 1999. p. 164-185.

KAHN, C. H. The Origins of social contract theory. Hermes, v. 44, p. 92-108, 1981.

KERFERD, G. B. O movimento sofista. São Paulo: Loyola, 2003.

MENEZES, L. M. B. R. Nova interpretação da passagem 359d da república de Platão. Kriterion, v. 53, n. 125, p. 29-39, 2012.

. Poderia a narrativa do Gyges de Platão ser uma ficção baseada em Heródoto? Transformação, v. 36, n. 3, p. 9-22, 2013.

$1-19,2014$.

O lógos dos polloí no argumento de Gláucon. Filosofia Unisinos, v. 15, n. 1, p.

OSTWALD, M. Nomos and the beginning of the Athenian Democracy. Oxford: Oxford University Press, 1969.

PEREIRA, M. H. R. A república. Tradução de Maria Helena da Rocha Pereira. 9. ed. Lisboa: Fundação Calouste Gulbenkian, 2001.

RIBEIRO, L. F. B. Antifonte. Tradução de Luís Felipe Bellintani Ribeiro. São Paulo: Loyola, 2008.

ROMILLY, J. La Loi dans la pensée grecque. Paris: Les Belles Lettres, 2002.

SCHALCHER, M. G. F. F. O anel de Giges: um quiasma Platônico. Revista Filosófica Brasileira, v. 4, n. 3, p. 105-109, 1988.

SLINGS, S. R. Platonis rempvblicam, recognovit brevique adnotatione critica instrvxit: S. R. Slings. Oxford: Oxford University Press, 2003.

STURTZ, F. G. Etymologicum graecae lynguae gudianum: qvas digessit et vna cvm svis edidit F. G. Stvrtzivs. Lipsiae: Literis, 1818.

SYLBURG, F. Etymologicon Magnum: opera Friderici Sylbvrgii veterani. Lipsiae: Editio Nova Correctior, 1816.

VEGETTI, M. Platone. La repubblica. Traduzione e commento a cura di Mario Vegetti. Napoli: Bibliopolis, 1998. V. 1-2.

Recebido em 02/03/2016

Aceito em 21/06/2016 